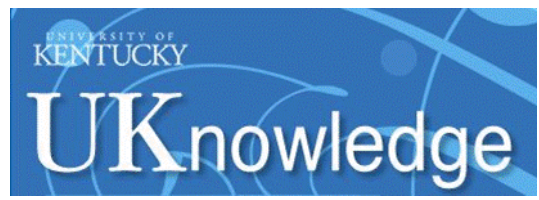

University of Kentucky

UKnowledge

Preventive Medicine and Environmental Health

Faculty Publications

Preventive Medicine and Environmental Health

9-12-1997

\title{
Use of Rollover Protective Structures - lowa, Kentucky, New York, and Ohio, 1992-1997
}

\author{
Craig Zwerling \\ University of lowa \\ Leon Burmeister \\ University of lowa \\ S. Reynolds \\ University of lowa \\ Robert H. McKnight \\ University of Kentucky, robert.mcknight@uky.edu \\ Steven R. Browning \\ University of Kentucky, srbrown@uky.edu
}

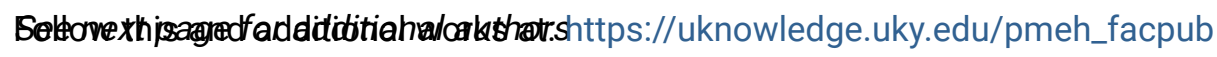

Part of the Environmental Public Health Commons

Right click to open a feedback form in a new tab to let us know how this document benefits you.

\section{Repository Citation}

Zwerling, Craig; Burmeister, Leon; Reynolds, S.; McKnight, Robert H.; Browning, Steven R.; Reed, Deborah; Wilkins, John III; Bean, T.; Mitchell, L.; Hallman, Eric; May, John J.; and Stark, A., "Use of Rollover Protective Structures -- lowa, Kentucky, New York, and Ohio, 1992-1997" (1997). Preventive Medicine and Environmental Health Faculty Publications. 26.

https://uknowledge.uky.edu/pmeh_facpub/26

This Article is brought to you for free and open access by the Preventive Medicine and Environmental Health at UKnowledge. It has been accepted for inclusion in Preventive Medicine and Environmental Health Faculty Publications by an authorized administrator of UKnowledge. For more information, please contact UKnowledge@lsv.uky.edu. 


\section{Use of Rollover Protective Structures -- lowa, Kentucky, New York, and Ohio,}

1992-1997

\section{Notes/Citation Information}

Published in Morbidity and Mortality Weekly Report, v. 46, no. 36, p. 842-845.

All material in the MMWR series is in the public domain and may be used and reprinted without special permission; citation as to source, however, is appreciated.

\section{Authors}

Craig Zwerling, Leon Burmeister, S. Reynolds, Robert H. McKnight, Steven R. Browning, Deborah Reed, John Wilkins III, T. Bean, L. Mitchell, Eric Hallman, John J. May, and A. Stark 


\section{MMWR}

Weekly

September 12, 1997 / 46(36);842-845

The content, links, and pdfs are no longer maintained and might be outdated.

- The content on this page is being archived for historic and reference purposes only.

- For current, updated information see the MMWR website.

\section{Use of Rollover Protective Structures -- Iowa, Kentucky, New York, and Ohio, 1992-1997}

Agriculture has one of the highest occupational fatality rates of all industries in the United States (1). Tractors and other types of agricultural equipment account for a large proportion of these fatalities, and farm-tractor rollovers account for approximately 130 work-related deaths each year in the United States (2). Although rollover protective structures (ROPS) are effective in protecting tractor operators from fatal injuries during rollovers (3-5), most tractors in the United States are not equipped with ROPS (4-7). Beginning in 1985, tractor manufacturers in the United Sates agreed to sell only tractors with ROPS; however, many older tractors without ROPS remain in use. To determine the prevalence of the use of ROPS, beginning in 1992, the Farm Family Health and Hazard Surveillance (FFHHS) program * collected state-based data on tractor age and use of ROPS from selected states. As of August 1997, four states had completed collection and analysis of data on farm tractors. This report summarizes the results of that survey, which indicates that $80 \%-90 \%$ of tractors in use in the four states were manufactured before 1985 and that less than $40 \%$ are equipped with ROPS.

FFHHS included population-based, cross-sectional surveys of health conditions and exposures to workplace hazards among farmers in six states (California, Colorado, Iowa, Kentucky, New York, and Ohio). For this report, data from four of these states were analyzed, including use of ROPS (Iowa, Kentucky, New York, and Ohio), year of tractor manufacture (Iowa, Kentucky, and Ohio), and the mean annual usage for these tractors (Iowa). The design of the surveys varied slightly from state to state. ROPS data were collected through a combination of telephone interviews (Iowa and Kentucky) and/or on-farm observational walkthroughs (Kentucky, New York, and Ohio).

Sampling frames varied by state and included all farms in the respective geographic study areas (Iowa and New York), only farms operated by farmers aged greater than or equal to 55 years (Kentucky), and only cash grain farms (Ohio). The surveys were designed to provide prevalence estimates either for a specific geographic area within the state (New York and Ohio) or statewide (Iowa and Kentucky). State-specific prevalence estimates were based on numbers of sampled farms and tractors: Iowa -- 344 farms, 1128 tractors; Kentucky -- 149 farms, 282 tractors; New York -- 580 farms, 2513 tractors; and Ohio -- 315 farms, 919 tractors.

The proportions of tractors with ROPS varied inversely with the age of the tractors, and the numbers of older tractors in use at the time of the survey were substantial. Overall, the percentage of tractors equipped with ROPS was greatest in Iowa (39.5\%) followed by New York (38.6\%), Ohio (34.3\%), and Kentucky (26.9\%) (Table 1). The percentage of tractors manufactured since 1985 that were equipped with ROPS ranged from 79.7\% (Kentucky) to 91.5\% (Ohio). However, among tractors manufactured during 1955-1964 (approximately 
15\% of all tractors), less than 5\% were equipped with ROPS, and among tractors manufactured before 1955 (approximately 13\% of tractors), less than 1\% were equipped with ROPS.

In Iowa, information was collected about the annual hours of use of tractors with and without ROPS (Table 2 ). Approximately 70\% of tractors without ROPS in Iowa, representing an estimated 114,246 tractors statewide, were used for greater than 100 hours each year. In 1995, the Iowa FFHHS asked farmers about tractors they had purchased during the previous year. A total of 45 farmers reported having purchased 63 tractors with a mean age of 18 years. Of these tractors, 25 (40\%) were not equipped with ROPS.

Reported by: C Zwerling, MD, L Burmeister, PhD, S Reynolds, PhD, Univ of Iowa, Iowa City. R McKnight, ScD, S Browning, PhD, D Reed, PhD, Univ of Kentucky, Lexington. J Wilkins, DrPH, T Bean, PhD, L Mitchell, MAS, Ohio State Univ, Columbus. E Hallman, MS, Cornell Univ, Ithaca; J May, MD, New York Center for Agricultural Medicine and Health, Cooperstown; A Stark, DrPH, S Hwang, PhD, New York State Dept of Health. Div of Surveillance, Hazard Evaluations, and Field Studies, Div of Safety Research, National Institute for Occupational Safety and Health; Div of Unintentional Injury Prevention, National Center for Injury Prevention and Control, CDC.

\section{Editorial Note}

Editorial Note: The number of tractors in the United States equipped with ROPS has been estimated by CDC's Traumatic Injury Surveillance of Farmers (TISF) survey. TISF contains data from a random sample of farming operations across the United States and provides information on lost-time, work-related farm injuries and data about farm tractors used on these farms. Based on information for 1993, TISF indicated that the hours of tractor use, distribution of the age of tractors in use, and ROPS-use patterns were similar to those presented in this report for Iowa, Kentucky, New York, and Ohio (6).

In 1993, an estimated 4.8 million tractors were in use on U.S. farms (6). Of these, only 38\% were equipped with a ROPS. However, 87\% of the farm tractors manufactured since 1985 are reported to be equipped with ROPS, and $92 \%$ of the farm tractors manufactured since 1990 were equipped with ROPS. In comparison, for farm tractors aged greater than or equal to 30 years (approximately 28\% of tractors on farms), less than $5 \%$ are equipped with ROPS.

The increase in installation of ROPS on tractors beginning in the mid-1980s especially reflects the 1985 American Society of Agricultural Engineers (ASAE) voluntary standard on ROPS (8) -- this standard encouraged all manufacturers of farm tractors to install ROPS on all new tractors (tractors used in orchard and vineyard operations were exempted because of limitations of vertical clearances). Most tractor manufacturers responded to the voluntary standard by developing ROPS suitable for use on all types of farm tractors currently being manufactured. In addition, most manufacturers have developed ROPS retrofits for use on many older tractor models. Retrofit kits, including safety belts, are now offered to farmers at the manufacturer's cost. The combined use of safety belts and ROPS provide tractor operators with a high level of protection by ensuring that the operator remains within the zone of protection of the ROPS in the event of a rollover.

The ASAE standard has contributed substantially to reducing the risk for tractor-rollover-associated injuries among farmers and farm workers. However, no effective national program has been implemented to encourage retrofitting ROPS on the approximately 3 million tractors without ROPS that are currently in use on farms. CDC's National Institute for Occupational Safety and Health (NIOSH) and the Occupational Safety and Health Administration (OSHA) encourage the use of ROPS and safety belts on all farm tractors in the United States, and OSHA maintains a standard that requires ASAE-approved ROPS to be placed on all farm tractors manufactured after 1976. The OSHA standard is not actively enforced on farms with less than 11 employees, and family farms without other employees are exempt from OSHA regulations. NIOSH can promote ROPS use but has no authority to require their use.

In September 1997, the University of Iowa sponsored the Tractor Risk Abatement and Control Policy Conference in Iowa City, Iowa. A main focus of this conference was to identify innovative policies and 
programs to encourage installation of ROPS on tractors and to promote use of safety belts with ROPS.

\section{References}

1. Bureau of Labor Statistics. Fatal workplace injuries in 1995: a collection of data and analysis. Washington, DC: US Department of Labor, April 1997; report no. 913.

2. Etherton JR, Myers JR, Jensen RC, Russell JC, Braddee RW. Agricultural machine-related deaths. Am J Public Health 1991;81:766-8.

3. Thelin A. Epilogue: agricultural, occupational and environmental health policy strategies for the future. Am J Ind Med 1990;18:523-6.

4. CDC. Public health focus: effectiveness of rollover protective structures for preventing injuries associated with agricultural tractors. MMWR 1993;42:57-9.

5. Lehtola CJ, Marley SJ, Melvin SW. A study of five years of tractor-related fatalities in Iowa. Applied Engineering in Agriculture 1994;10:627-32.

6. Myers JR, Snyder KA. Rollover protective structure use and the cost of retrofitting tractors in the United States, 1993. J Agric Safety Health 1996;1:185-97.

7. Kelsey TW, May JJ, Jenkins PL. Farm tractors, and the use of seatbelts and rollover protective structures. Am J Ind Med 1996;30:447-51.

8. American Society of Agricultural Engineers. ASAE Standards. 32nd ed. S318.10, tractor rollover protection. St. Joseph, Minnesota: American Society of Agricultural Engineers, 1985.

* A cooperative agreement program funded by CDC's National Institute for Occupational Safety and Health to provide descriptive health and hazard data for a sample of farms in six states.

\section{Table_1}

Note: To print large tables and graphs users may have to change their printer settings to landscape and use a small font size.

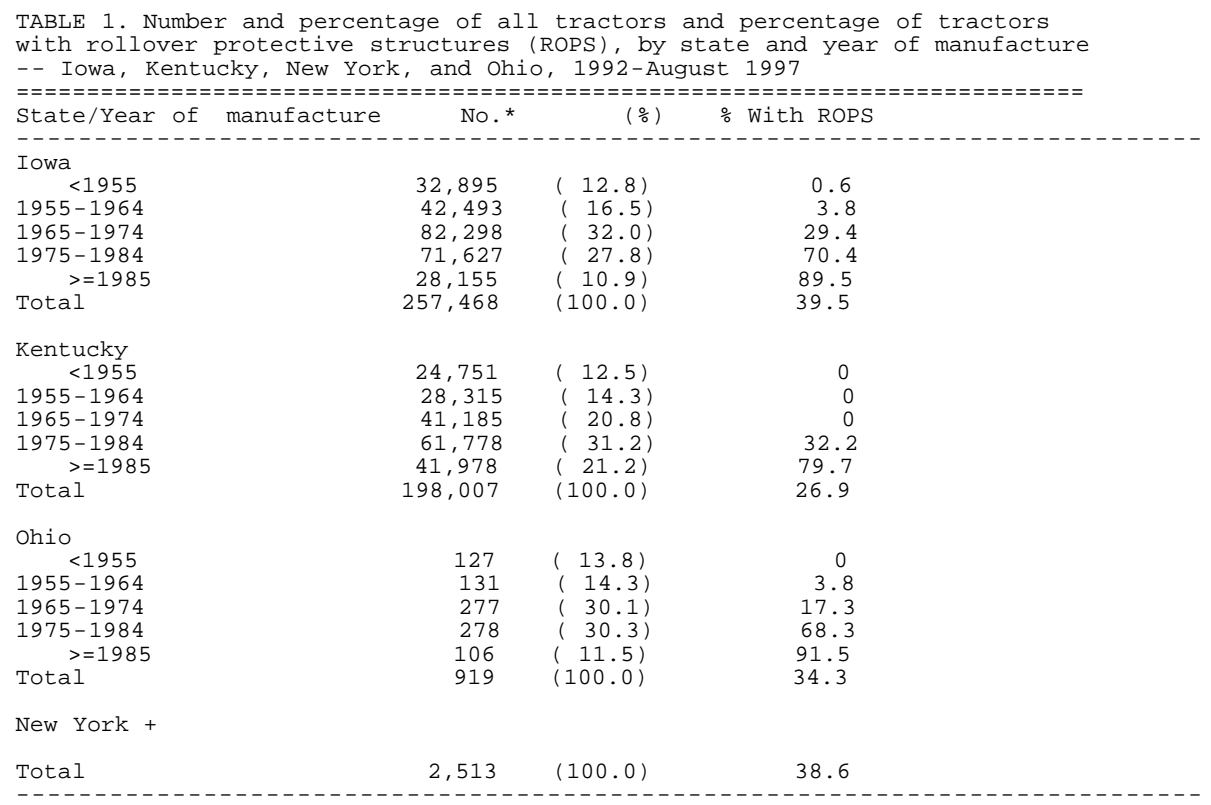

* Iowa and Kentucky reported weighted estimates for tractors 


\section{Return to top.}

\section{Table_2}

Note: To print large tables and graphs users may have to change their printer settings to landscape and use a small font size.

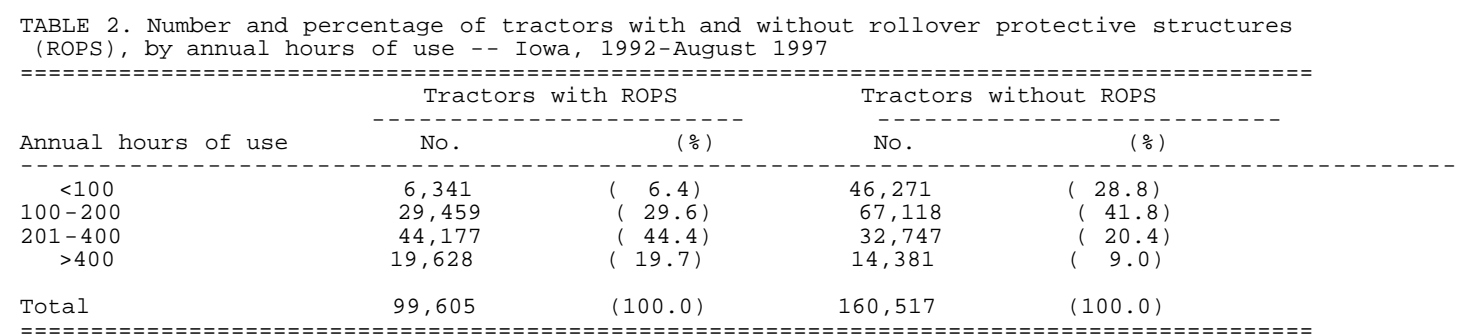

\section{$\underline{\text { Return to top. }}$}

Disclaimer All MMWR HTML versions of articles are electronic conversions from ASCII text into HTML. This conversion may have resulted in character translation or format errors in the HTML version. Users should not rely on this HTML document, but are referred to the electronic PDF version and/or the original $M M W R$ paper copy for the official text, figures, and tables. An original paper copy of this issue can be obtained from the Superintendent of Documents, U.S. Government Printing Office (GPO), Washington, DC 20402-9371; telephone: (202) 512-1800. Contact GPO for current prices.

**Questions or messages regarding errors in formatting should be addressed to mmwrq@cdc.gov.

Page converted: 09/19/98

HOME | ABOUT MMWR | MMWR SEARCH | DOWNLOADS | RSS | $\underline{\text { CONTACT }}$ POLICY | DISCLAIMER | ACCESSIBILITY

SAFER * HEALTHIER P PEOPLE: Morbidity and Mortality Weekly Report Centers for Disease Control and Prevention 1600 Clifton Rd, MailStop E-90, Atlanta, GA 30333. U.S.A
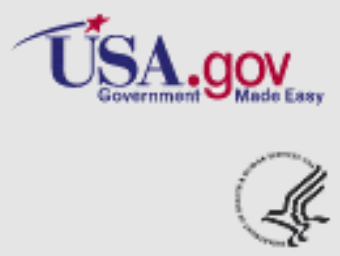

Department of Health and Human Services 